\title{
Sorption and Solubility Characteristics of Compomer, Conventional and Resin Modified Glass-Ionomer Immersed In Various Media
}

\author{
Dr. Shiji Dinakaran \\ Associate Professor, Department Of Conservative Dentistry \& Endodontics, Government Dental College, \\ Calicut, Kerala, India
}

\begin{abstract}
Tooth coloured adhesive restorative materials are widely accepted and used for the restoration of carious and non-carious cervical lesions. The aim of this study was to evaluate and compare the solubility and sorption values of compomer (Dyract $\left.{ }^{\circledR}\right)$, conventional glass-ionomer(Fuji II ) and resin modified glassionomer (Fuji II LC improved) cements in various beverages such as tea, coffee, coca-cola and lime with saline as control. Twenty five circular discs per restorative material were prepared. Five specimens of each material were kept immersed in the test media and saline for seven days. Water sorption and solubility were calculated using ISO guidelines. Statistical analysis revealed statistically significant difference $(P<0.05)$ between the three test materials. Among the media tested lime influenced both sorption and solubility values more than the other media. Fuji II was found to have more sorption and solubility values than the other two materials.
\end{abstract}

Key words: coca-cola, erosive potential, lime, solubility, sorption

\section{Introduction}

Advancements in preventive dentistry had led to the prevalence of non carious cervical lesions in the oral cavity. Such lesions with exposed areas of cementum and dentin needs attention both from aesthetic point of view as well as sensitivity. Carious cervical lesions are more common in patients with high caries risk such as those with systemic disorders and poor oral hygiene Aesthetic adhesive restorative materials especially those with fluoride releasing ability are commonly used to restore such lesions. Fluoride incorporated materials such as glass- ionomer cements (GIC) have been indicated as the restorative material of choice for such lesions [1]. The aesthetic qualities and ease of placement makes such restorations satisfactory for both the patient and the clinician.

GIC are basically water based materials that consist of ion-leachable glass and water soluble polymeric acids which set by acid base reaction in the presence of water [2]. These materials are capable of forming chemical bonding with enamel and dentin, anticariogenicity, good biocompatibility and coefficient of thermal expansion close that of tooth structures [3]. As a restorative material, the chemical bond to enamel and dentin facilitates ion exchange of fluoride with the hydroxyl ions in the apatite of the surrounding enamel $[4,5]$. One of the most important changes in the composition of GIC was the addition of ingredients to allow light curing [6].

Resin modified glass- ionomers retain a significant acid/ base reaction as part of their overall curing process. Resin modified specifically refers to the addition of polymerizable resin groups usually hydroxyethylmethacrylate (HEMA) by grafting them to molecules of the acidic liquid component. Only about 1 five percentage of the mixed cement will be resin [7]. Compomers are defined as "polyacid modified resins". They are basically light cured low fluoride releasing composite resins [8]. They differ from composites in that they contain acid functional group that can participate in an acid/base glass-ionomer reaction following polymerization of the resin molecule. However, they are not glass-ionomer materials.

Two important physical properties that influence the clinical durability of a restorative material are water sorption and solubility of the material. Water sorption can increase the volume of the material and it can act as a plasticizer and cause deterioration of the matrix structure of the material[9]. Sorption and solubility of tooth coloured restorative materials depend on various factors such as type of material, composition of matrix, filler particles, efficiency of polymerization as well as immersion media used [10,11]. In the oral cavity, the restorative materials used are immersed in various solutions such as water, fruit juices, tea, coffee and low $\mathrm{pH}$ carbonated drinks during their life time. The present study was conducted to evaluate and compare the water sorption and solubility of Conventional GIC (Fuji II) Resin modified GIC( Fuji II LC improved )and Compomer( Dyract $\left.{ }^{\circledR}\right)$ in various beverages such as tea, coffee, coca-cola and lime juice using saline as control.

\section{Materials And Methods}

The materials used for this study were Compomer (Dyract ${ }^{\circledR}$, DeTrey, Dentsply), Conventional glassionomer cement (Fuji II, G.C. Corp, Tokyo, Japan) and Resin modified glass-ionomer (Fuji II LC improved, GC 
Corp, Tokyo, Japan). Dyract ${ }^{\circledR}$ was supplied in the form of compules where as Fuji II and Fuji II LC improved were supplied as powder and liquid in separate bottles. The composition of the test materials is given in TABLE-1.The test media used for this study were $0.9 \%$ saline (RUSOMA Laboratories, Indore, Batch No. 087P, 091A), Coca-cola (Coca - cola co, Kerala, Batch No. 395), tea (prepared by adding 1 teaspoon tea dust to $160 \mathrm{ml}$ of water, coffee (prepared by adding 1 teaspoon of coffee powder to $160 \mathrm{ml}$ water) and lime juice (prepared by adding $5 \mathrm{ml}$ of lime extract to $160 \mathrm{ml}$ of distilled water).

The solubility and sorption of Dyract @ (Group I), Fuji II (Group II) and Fuji II LC improved (Group III) were tested in all the five above mentioned test media according to ISO Guidelines specification No. $4049: 2009$ (E) [12]. Three split stainless steel moulds with circular holes of fifteen millimeter diameter and two millimeter thickness were used for preparing the specimens. Total of twenty five samples were prepared for each material.

For compomer (Dyract ${ }^{\circledR}$ ) the specimens were prepared by exposing compomer pastes packed in stainless steel mould to the visible light source (Cure Rite @ visible curing unit, Dentsply) for forty seconds from the top for three overlapping increments. The powder and liquid of Fuji II were mixed on a mixing pad as per the manufacturer's instructions and were then packed into the stainless steel mould. The material was allowed to set in the mould. For Fuji II LC improved the mixed material was packed into the mould and cured from the top using visible light source for twenty seconds for three overlapping increments.

TABLE 1 (COMPOSITION OF TEST MATERIALS)

\begin{tabular}{|c|c|c|c|c|c|}
\hline Group & Material & Powder Liquid & Type of & Composition & Manufactures \\
\hline & & ratio $(g / g)$ & Material & & \\
\hline I & Dyract $®$ & Compule & Compomer & $\begin{array}{l}\text { UDMA resin, TCB resin, strontium - } \\
\text { fluoro-silicate glass, strontium } \\
\text { fluoride, photo initiators, stabilizers }\end{array}$ & DeTrey, Dentsply \\
\hline II & Fuji II & $2.7: 1$ & $\begin{array}{l}\text { Conventional } \\
\text { glass ionomer }\end{array}$ & $\begin{array}{l}\text { Powder - Fluoroaluminosilicate glass } \\
\text { Liquid - Copolymer of acrylic and } \\
\text { maleic acids, polybase carboxylic } \\
\text { acid, water }\end{array}$ & $\begin{array}{l}\text { GC Corp, Tokyo, } \\
\text { Japan }\end{array}$ \\
\hline III & Fuji II LC & $3: 1$ & $\begin{array}{l}\text { Resin } \\
\text { modified } \\
\text { glass ionomer }\end{array}$ & $\begin{array}{l}\text { Powder - Aluminosilicate glass, } \\
\text { pigments } \\
\text { Liquid - Poly acrylic acids, distilled } \\
\text { water,HEMA(17\%),Dimethacrylate } \\
\text { monomer, camphoroquinone }\end{array}$ & $\begin{array}{l}\text { GC Corp; Tokyo } \\
\text { Japan }\end{array}$ \\
\hline
\end{tabular}

UDMA, Urethane dimethacrylate ; TCB , Carboxylic acid modified di methacrylate

HEMA, hydroxy ethylmethacrylate

The cleaned and polished samples were first transferred to a desiccator maintained at $37^{\circ} \mathrm{C}$ containing silica freshly dried for five hours.After twenty two hours the specimens were removed and stored in a second desiccator maintained at $23^{\circ} \mathrm{C}$ for two hours. Then they were weighed to an accuracy of $0.1 \mathrm{mg}$ in a digital analytic balance (Mettler digital analytical balance, Mettler Toledo, USA). This cycle was repeated till a mass of loss not more than $0.1 \mathrm{mg}$ in any twenty four hour period is achieved. This is the initial dry weight $\left(\mathrm{M}_{1}\right)$

Two measurements of diameter were taken at right angles to each other using dial caliper (Starrett 1202 -4 dial caliper, Starrett, USA) and mean diameter was calculated. Thickness was measured at the center of the specimen and at four equally spaced points. Area was calculated in millimeter ${ }^{2}$ from the mean diameter and volume was calculated in millimeter ${ }^{3}$.

Five samples of each material were then immersed in $10 \mathrm{ml}$ of various test media at $37^{\circ} \mathrm{C}$ for seven days. The test media were freshly prepared and replaced in every twenty four hours. After seven days, the specimens were removed, washed in distilled water and the surface adherent water was gently blotted away with a tissue paper. After removal of the visible moisture, there were waved in air for fifteen seconds and weighed in the balance $\left(\mathrm{M}_{2}\right)$.This was followed by reconditioning the specimens to constant weight in the desiccator using the earlier cycle. The constant mass was recorded - final dry weight $\left(\mathrm{M}_{3}\right)$. The solvent uptake and solubility were determined in $\mu \mathrm{g} / \mathrm{mm} 3$ using the Oysaed and Ruyter formula.

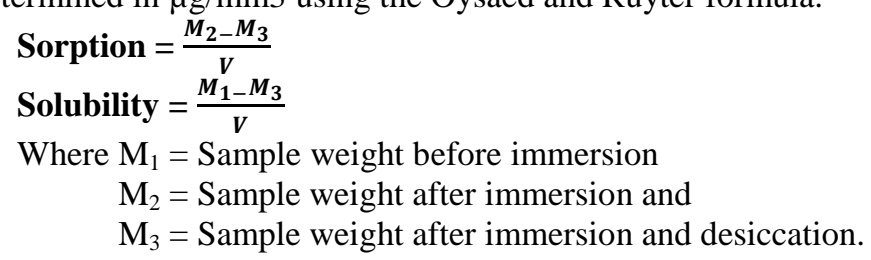




\section{Results}

The data obtained was statistically analyzed using one way analysis of variance (One way ANOVA) and two way ANOVA. P values less than 0.05 were considered statistically significant. One way ANOVA of solubility and sorption value in all media for the three tested materials are summarized in TABLE -2 . These results are presented graphically in Fig.1 and 2.

Table 2Mean Values ( \pm Standard Deviation) Of Solubility And Sorption Of Three Test Materials In Five Immersion Media

\begin{tabular}{|c|c|c|c|c|c|c|c|c|}
\hline \multirow[b]{2}{*}{ Property } & \multirow[b]{2}{*}{ Material } & \multicolumn{5}{|c|}{ Immersion Media } & \multirow[b]{2}{*}{$\mathrm{F}$} & \multirow[b]{2}{*}{$\mathrm{P}$} \\
\hline & & $\begin{array}{c}\text { Group A } \\
\text { Tea }\end{array}$ & $\begin{array}{c}\text { Group B } \\
\text { Coffee }\end{array}$ & $\begin{array}{c}\text { Group C } \\
\text { Coco Cola }\end{array}$ & $\begin{array}{l}\text { Group D } \\
\text { Lime }\end{array}$ & $\begin{array}{c}\text { Group E } \\
\text { Saline }\end{array}$ & & \\
\hline \multirow{3}{*}{ Solubility } & Dyract $\AA$ & $\begin{array}{l}4.3703^{b} \\
\pm 0.8762\end{array}$ & $\begin{array}{l}4.3900^{b} \\
\pm 0.8116\end{array}$ & $\begin{array}{l}17.2460^{\mathrm{c}} \\
\pm 1.052\end{array}$ & $\begin{array}{l}21.8287^{\mathrm{d}} \\
\pm 1.9448\end{array}$ & $\begin{array}{l}1.3113^{\mathrm{a}} \\
\pm 0.0969\end{array}$ & $\begin{array}{l}36.19 \\
4\end{array}$ & $<0.01$ \\
\hline & Fuji II & $\begin{array}{l}30.2300^{\mathrm{b}} \\
\pm 1.9605\end{array}$ & $\begin{array}{l}30.3193^{b} \\
\pm 1.6125\end{array}$ & $\begin{array}{l}51.2047^{\mathrm{c}} \\
\pm 7.2192\end{array}$ & $\begin{array}{l}89.7560^{\mathrm{d}} \\
\pm 4.9623\end{array}$ & $\begin{array}{l}21.4710^{\mathrm{a}} \\
\pm 4.8864\end{array}$ & $\begin{array}{l}109.3 \\
41\end{array}$ & $<0.01$ \\
\hline & $\begin{array}{l}\text { Fuji II LC } \\
\text { improved }\end{array}$ & $\begin{array}{l}25.9677^{\mathrm{a}} \\
\pm 6.0036\end{array}$ & $\begin{array}{l}25.7400^{\mathrm{a}} \\
\pm 3.1790\end{array}$ & $\begin{array}{l}37.0093^{\mathrm{b}} \\
\pm 5.6972\end{array}$ & $\begin{array}{l}64.9370^{\mathrm{c}} \\
\pm 4.8531\end{array}$ & $\begin{array}{l}20.4283^{\mathrm{a}} \\
\pm 0.5044\end{array}$ & $\begin{array}{l}46.86 \\
0\end{array}$ & $<0.01$ \\
\hline \multirow[t]{3}{*}{ Sorption } & Dyract $\AA$ & $\begin{array}{l}12.2307^{\mathrm{a}} \\
\pm 0.5643\end{array}$ & $\begin{array}{l}12.0683^{\mathrm{a}} \\
\pm 0.7627\end{array}$ & $\begin{array}{l}14.3687^{\mathrm{b}} \\
\pm 0.3103\end{array}$ & $\begin{array}{l}15.4707^{c} \\
\pm 0.1239\end{array}$ & $\begin{array}{l}11.4767^{\mathrm{a}} \\
\pm 0.1381\end{array}$ & $\begin{array}{l}42.49 \\
7\end{array}$ & $<0.01$ \\
\hline & Fuji II & $\begin{array}{l}203.9430^{\mathrm{a}} \\
\pm 11.4745\end{array}$ & $\begin{array}{l}205.1847^{\mathrm{a}} \\
\pm 9.0335\end{array}$ & $\begin{array}{l}240.3300^{b} \\
\pm 7.1619\end{array}$ & $\begin{array}{l}251.6710^{b} \\
\pm 3.5994\end{array}$ & $\begin{array}{l}201.4370^{\mathrm{a}} \\
\pm 7.8667\end{array}$ & $\begin{array}{l}24.71 \\
6\end{array}$ & $<0.01$ \\
\hline & $\begin{array}{l}\text { Fuji II LC } \\
\text { improved }\end{array}$ & $\begin{array}{l}195.4023^{\mathrm{a}} \\
\pm 5.1160\end{array}$ & $\begin{array}{l}195.8703^{\mathrm{a}} \\
\pm 10.2903\end{array}$ & $\begin{array}{l}207.1450^{b} \\
\pm 4.2058\end{array}$ & $\begin{array}{l}218.6717^{b} \\
\pm 12.4168\end{array}$ & $\begin{array}{l}192.8017^{\mathrm{a}} \\
\pm 2.6425\end{array}$ & 5.673 & $<0.01$ \\
\hline
\end{tabular}

With respect to each test material means with same superscript do not vary significantly.

Figure 1: Solubility of Compomer, Conventional GIC and Resin Modified GIC in various media
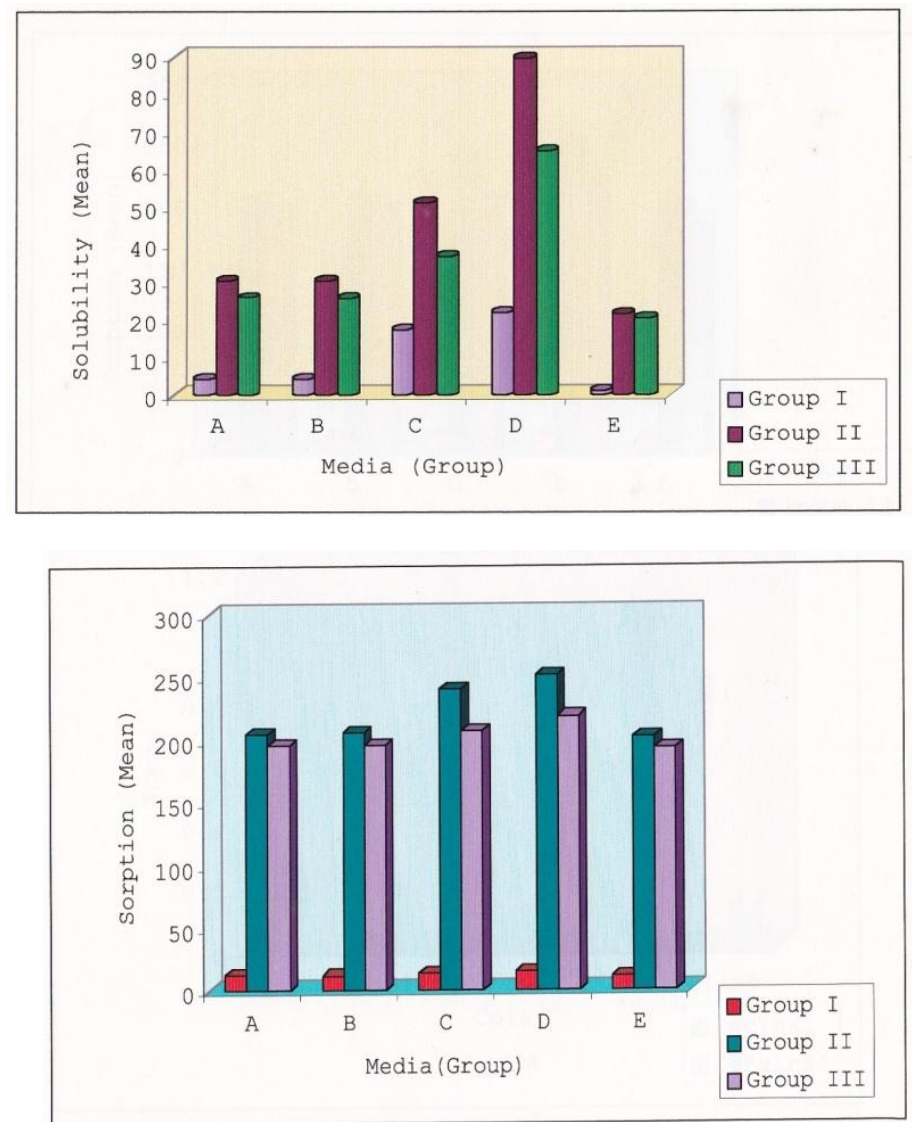

Figure 2: Sorption of Compomer, Conventional GIC and Resin Modified GIC in various media 


\section{Discussion}

One of the main factors that determine the durability of a material used in the oral environment is its chemical stability. Standard test of sorption and solubility as used in this study involves the storage of disc specimens of materials in water/media for a period of time, the result being quoted as weight gain or weight loss of the disc respectively [9]. The property of sorption includes a combination of adsorption and absorption. Adsorption is a surface phenomena while absorption involves penetration of liquid molecules into the structure of the solid material mainly through diffusion [13]. The $\mathrm{pH}$ of oral cavity varies from acidic to alkaline depending on the foods consumed as well as the salivary changes in each individual. The modern dietary habit of frequent consumption of low $\mathrm{pH}$ carbonated drinks can alter the oral environment to an acidic range.

When the restorative materials are exposed to or stored in water, two different mechanisms occur. First there will be uptake of water producing an increased weight (sorption) and leaching or dissolution of components from the material into the mouth (solubility) leading to reduction in weight [9]. Conventional glass-ionomer cements have a major drawback of moisture sensitivity until the completion of its setting reaction [14]. This could be related to the present study from the high values of water sorption and solubility of conventional glass-ionomer cement (Fuji II) in all the five immersion media. This is because water is absorbed due to elution of cement forming cations. But with the increasing development of the cement structure, there is decreased water penetration [15].

In the present study the three materials tested shows high values of sorption and solubility in lime juice. This result infers that lime juice is having an enhancing effect on these two properties than the other immersion media such as tea, coffee, saline and coca cola. In case of Dyract ${ }^{\circledR}$ the solubility values in both coca cola and lime exceeds the maximum acceptable values for polymer based restorative materials $\left(7.5 \mu \mathrm{g} / \mathrm{mm}^{3}\right)$ [14]. For Fuji II and Fuji II LC the solubility values are far higher than that of Dyract $₫$ in all the five immersion media. In case of Fuji II and Fuji II LC improved the material have to be blended. The method of mixing may generate air voids, which may accelerate the water sorption and solubility of these cements [17]. Air voids incorporated in the material increases the surface exposed to moisture and may lead to inhibition zones with unpolymerized material in case of Fuji II LC improved [17]. The loss of the siliceous hydrogel can lead to matrix dissolution and this in turn can cause loss of surface hardness of glass-ionomers [18]. Moreover the presence of hydrophilic constituent HEMA in Fuji II LC improved can increase its water sorption ability. The conventional glassionomer material specimens were not protected after setting with any hydrophobic layer. This may also be a reason for their high values.

The lower values of sorption and solubility of Dyract ${ }^{\circledR}$ compared to the other two test materials indicate that there is only a weak acid -base reaction in these materials [9]. Acid base reaction is initially limited in this type of material because of its anhydrous structure, but once water is absorbed, delayed acid base reaction is likely [19]. The sorption values of Dyract $₫$ in all five immersion media were within the maximum acceptable value of $40 \mu \mathrm{g} / \mathrm{mm}^{3}$ [16]. This indicate that the immersion medias even though increased the sorption value of Dyract ${ }^{\circledR}$ especially in lime followed by coca cola, they were within the limits of acceptable standards.

Fruit juice (lime) and Coca-cola increased solubility of three materials tested, a finding similar to their involving the effect of these beverages on loss of surface hardness of glass-ionomers and compomers [20]. Phosphoric acid is normally used in cola drinks while citric acid predominates in fruit juices [21]. Citric acid was found to have more erosive potential on enamel and dentin [21]. This could be related to the high solubility and sorption values in limejuice in the present study. The result of this study suggest that common food beverages such as citrus fruits and low $\mathrm{pH}$ carbonated drinks which have an acidic $\mathrm{pH}$ in the range to dissolve enamel and dentin can also cause deterioration of the restorative materials commonly used to restore such erosive lesions. Among the three tested materials compomer (Dyract ${ }^{\circledR}$ ) has less solubility and sorption characteristics. The solubility of Dyract ${ }^{\circledR}$ was higher than the maximum acceptable value $\left(7.5 \mu \mathrm{g} / \mathrm{mm}^{3}\right)$ in lime and coca-cola but sorption values in all test media were within limits. Even though Fuji II LC improved has statistically lesser values of sorption and solubility compared to Fuji II sorption and solubility values of both materials were beyond the maximum limits of $40 \mu \mathrm{g} / \mathrm{mm}^{3}$ and $7.5 \mu \mathrm{g} / \mathrm{mm}{ }^{3}$ respectively (16). The sorption values of all three test materials in tea, coffee and saline do not vary significantly $(\mathrm{P}<0.05)$. Both Fuji II and Fuji II LC had no statistically significant variation in their sorption values in lime and coca cola.

\section{Conclusion}

With the limitations of this in vitro study it can be concluded that acidic fruit juices and low $\mathrm{pH}$ carbonated drinks can influence the properties of tooth coloured adhesive materials used to restore cervical lesions. So a change in dietary habit of the patient is needed in addition to restoration to retain such restorations and prevent further progression of non- carious and carious cervical lesions and their complications. 


\section{References}

[1] Powell L.V, Gordon E.E, Johnson G.H, Clinical evalution of direct esthetic restorations in cervical abrasion /erosion lesions: one year results, Quintessence Int., 22(9), 1991, 687 - 692.

[2] Francisconi L.F, Scaffa P.M, Barros V.R, Coutinho M, Francisconi P.S, Glass Ionomer Cements and their role in the restoration of non-carious cervical lesions,J Appl Oral Sci., 17(5), 2009, 364 - 369.

[3] Kovarik R.E, Haubenreich J.E Gore D. Glass Ionomer Cements : a review of composition, chemistry and biocompatibility as a dental and medical implant material. J Long Term Eff Med Implants ., 15 (6), 2005, 655 - 671.

[4] Billington R.W, Peason G.T, Williams J.A, Uptake of fluoride ions by the glass component of glass ionomer cement. J.Dent;35(5), $2007,452-455$

[5] Powis D.R, Follerias T, Merson S.A, Wilson A.D, Improved adhesion of a glass-ionomer cement to dentin and enamel. J Den. Res, 6(12), 1982, $1416-1422$

[6] Ozgunaltay G, Onen A, Three year clinical evalution of a resin modified glass -ionomer cement and a composite resin in noncarious class V lesions. J Oral Rehabil, 29 (11), 2002, 1037 -1041.

[7] Mathis R.S, Ferracane J.L, Properties of a glass-ionomer resin composite hybrid material. Dental Mater; 5(5), 1989, 355 - 358

[8] Gordon J, Christensen, Compomers si Resin reinforced glassionomer. JADA, Vol: 128, 1997, $479-480$.

[9] Manuel Toledano, Osorio R, Osorio E, Prati C, Garcia Godoy F, Sorption and solubility of resin based restorative dental materials. J Dent, 31 (1), 2003, $43-50$.

[10] Von Fraunhofer J.A, Curtis P. Jr, Physical and mechanical properties of anterior and posterior composite restorative materials, Dent Mater, (5), 1989, $365-368$

[11] Moharamzadeh K, Van Noort R, Brook I.M, Scutt A.M, HPLC analysis of components released from dental Composites with different resin compositions using different extraction media. J Mater Sci Mater Med, (18), 2007, 133 -137.

[12] ISO 4049 : 2009 (E) Dentistry Polymer - based restorative materials Geneve : International Organization for Standardization, Switzerland; 2009

[13] WJOB, Dental Materials and their Selection $4^{\text {th }}$ edtn. (Quintessence Pub Co., 2008, 9)

[14] Van de Voorde A, Gerdts G.J, Murchison, Clinical uses of glassionomer cement: a literature review. Quintessence International , 19(1), 1998, $53-61$

[15] Mesu F.P, Reedy K.T, Degradation of luting cements measured invitro and invivio. J Dental Research, 62(12), 1983,1236 - 1240.

[16] Janda R, Roulet J.F, Latta M, Rutter mann S. Water sorption and solubility of contemporary resin - based filling materials. J Biomed Mater Res B Appl Biomater, 82, 2007, 545 - 51.

[17] Chinelatti A.M, Ramos R.P, Chimello D.T, Palma - Dibb RG, Clinical performance of a resin modified glass-ionomer and two Poly acid modified resin composites in cervical lesions restoration: one year follow up. J Oral Rehabil31, 2007, 251 - 257.

[18] Turssi C.P, Hara A.T, Serra M.C, Rodrigues AL. Jr. Effect of storage media upon the surface micro morphology of resin based restorative materials, J Oral Rehabil, 29 (9), 2002, 864 - 871

[19] Meyer J.M, Cattani - Lorente M.A, Dupuis V, Compomers: between glass-ionomers cements and composites. Biomaterials 19, $1998,529-39$.

[20] Aliping MC Kenzie M, Linden RWA, Nicholson JW. The effect of Coca-cola and fruit juices on the surface hardness of glassionomers and compomers: Journal of Oral rehabil, 31 (11), 2004, $1046-1052$.

[21] West NX, Hughes JA, Addy M. The effect of pH on the erosion of dentine and enamel by dietary acids invitro J Oral Rehabil, 28(9), 2001, 860 - 864 . 